\title{
Topical questions of the substitute family care in the Czech Republic with a special attention to the process of foster families preparation
}

\author{
Iva Junova and Gabriela Slaninova* \\ University of Hradec Kralove, Czech Republic
}

\begin{abstract}
Authors deal with the substitute family care in the Czech Republic. Attention is concentrated on a conception of the substitute family care as a form of a children care in that children are raised by "substitute" parents in an ambience that is very similar to a natural family life. In the Czech Republic, the substitute family care is always preferred to an institutional upbringing. The aim of the article is to describe the system of the substitute family care in the Czech Republic and to introduce a foster care as one of the institutes of the substitute family care. Authors paid attention to a foster care and to a temporary foster care in the context of a professional preparation of foster families. The professionally led preparation in the Czech Republic is legally regulated by performing some law provisions of the social and legal children protection.
\end{abstract}

Key words: substitute family care, family functions, custody, foster care, tutelage, adoption.

\section{Introduction}

A family works as the most important factor in a process of socialization and upbringing of a child. It significantly impacts an initial development and a formation of child's personality. It also participates in a creation of child's lifestyle and child's value orientation. A family provides care and material security, it shows solidarity with all its members and plays an irreplaceable role in the process of emotional background creation for its members, and it has to ensure a sense of safety and security.

A family carries out a lot of functions towards its members and towards our society. Family functions undergo development and react to a current situation and needs of our society. Stašová or Kraus mention family functions enumeration [1,2].

Below mentioned family functions are the most significant ones:

- Biological-reproductive - has an importance for an individual and also for the society. The heart of this function does not change, but parents' point of view on their children does - especially in the developed countries. The child is being viewed as an obstacle in parent's career or in their self-realization. Some families have to consider their financial situation at the moment when they intend to have a child.

\footnotetext{
* Corresponding author: gabriela.slaninova@uhk.cz
} 
Those are the reasons why birth rate is declining and the number of children in families is smaller (compared with foe example during the post-war period) are common in the developed countries nowadays.

- Social-economic - living in abundance is one of the leading conditions of feeling life satisfaction in contemporary Czech families. This was proved by e.g. An exploration of Czech family lifestyle [3].

- Protective (caring) - especially in the socialism era the state strongly interfered in providing the necessities of life and the health care in the Czech Republic. At present families are responsible for satisfying this function. Due to this responsibility some families may have increased financial and time strain. This is the reason why the function is sometimes being satisfied only in a limited range and quality.

- Socializing-educating - a family plays a key role in the process of preparing children for their future practical life. A child acquires habits and good manners in the society. In pursuance of family members' socializing interaction it is necessary to understand both positive and negative influences and examples. Also other factors enter into the process of socialization (school, children of the same age, mass media) and they may create opposite pressures and requires. There are also risks in unsuitable upbringing styles, e.g., too liberal or too authoritative. Changes may be observed also in intergenerational relationships, this topic was processed by Ondrejkovič [4].

- Recreational - it is typical of contemporary lifestyle in developed countries that children have historically more leisure time, but they cannot use it very well. Families have to teach children how to use their leisure time actively by hobbies that encourage child's personality development, individual predisposes and talents. The skill to relax well is one of the main requirements of the healthy lifestyle education.

- Emotional - is a function that is essential and irreplaceable. When it comes to a failure in one of above mentioned functions, family may be substituted by a society and its system of social, health, educational and other institutions. In case of emotional function failure it is not possible to replace it by anything.

Apart from above mentioned reasons the fulfilling of family functions is being endangered by other circumstances which are a reflection of a changing Czech society. Contemporary Czech families have to face phenomena as a growing isolation, disintegration of family life, considerable parental workload, lack of time to spend together, high divorce rate, etc.

There exists an institute for substitute family care in the Czech Republic for cases when families cannot fulfil their functions due to above mentioned reasons. Bubleová and Kovaříksay that this in practice means "...the child is being brought up by "substitute" parents in the environment, that is as similar to the life in the natural family as possible" $[5,7]$. Concord among Nožírová may be generally said that the issue is an option of an unshared care of children who cannot grow up in their own family or are not brought up by their biological parents [6]. According to article 971 of the Civil code a substitute family care is always preferred to an institutional care. A substitute family care is established and also expires by the judicial decision. In the Czech Republic the substitute family care is protected by the Constitution of the Czech Republic, Convention on Rights of the Child, also in chapters II and III of the second part of the act No. 2012-89 Coll. Civil Code, in the act No. 1999-359 Coll. on the Social and Legal Protection of Children, in the act No. 2013-292 Coll. on Special Court Procedures and in act No. 1963-99 Coll. Civil Procedure [7]. First of all the court has to find out whether it is possible to entrust a child to the care of some close person or acquaintance or not. After this step a substitute parent is chosen from a group of vetted candidates for a substitute family care who are kept in a county Council registers. 
The substitute family care in the Czech Republic includes following forms: foster care, temporary foster care, boarding out a child with another natural person, tutelage, adoption.

The purpose of our study is the process of preparation for future foster parents so bellow this are in more detail described two substitute family care institutes - foster care and temporary foster care. Three remaining institutes will be described in brief.

\subsection{Foster care}

A foster care is mentioned in chapter III of the second part in articles $958-970$ and it is elaborated in detail in fifth part of the act No. 1999-359 Coll. on the Social and Legal Protection of Children.

It is a form of a substitute family care that is being considered in case when children cannot live with their biological families and cannot be entrusted to a care of some other natural person or to be adopted. In the family of a foster parent, for the child is ensured life that is similar to the life in a biological family. In the Czech Republic a foster parent may be a person who is related to the child, a person who is close to the child and also a person who is unfamiliar to the child. A child may by fostered out to an individual, a married couple or also only one individual from a married couple, but in this case an approval from the wife/husband of the individual is necessary [8]. A court may determine a foster care for an indefinite period of time or for a definite period of time as long as there is an obstruction in the family (e.g. family crisis etc.) that keeps biological parents from caring of their child. Parents may ask for returning their child in personal care and in case that it is in the interest of the child, the court may grant this request according to the article 959 of the act No. 2012-89 Coll.

A foster care is a service guaranteed and supported by state, since 1. 1. 2013 the foster care is viewed as a service for children. It came to a professionalization that gives foster parents duties and rights (detailed described in works of Bubleová or in the act No. 1999-359 Coll. on the Social and Legal Protection of Children) [8]. This is closely connected to the preparations that foster parents have to complete. It is also an obligation to make an agreement with an authorized organization or with the Authority for Social and Legal Protection of Children. Máliková (in Bubleová, 2014) claims that a part of the families support is also an inspection of a foster caring, providing education for foster parents [7]. For example, foster parents in the Czech Republic have to take part in twenty-four hours of specialized education. Foster parents are supposed to support and allow child to be in a contact with his or her biological parents unless the court has decided in a different way. Foster parents are eligible for so called foster parents allowance according to the act No. 1999-359 Coll. on the Social and Legal Protection of Children) [7].

\subsection{Temporary foster care}

The temporary foster care institute is confirmed in the Czech legal system since 2016. This institute specializes in a short-term care of children who temporary cannot live in their own families. Zimová and Bubleová mention that the meaning of a temporary foster care is to give an instant assistance to threatened children [7,8]. As those children are usually placed suddenly in a situation when they do not have a chance to be with their families, the Ministry of Labour and Social Affairs puts forward large requirements to foster parents:... it is the case of a very specific group of foster parents who should be professionally prepared, supervised and regularly professionally trained. Foster parents who are specialized in temporary foster caring should be stable personalities with good prerequisites and abilities to take care of a child. They have to have an adequate conveniences and they decidedly should be well informed about temporary foster care they had knowingly decided for [9]. 
The child may be put it the custody only by legal action when the Authority for Social and Legal Protection of Children submits a proposal. At least every three months the court has to review whether the reasons for carrying out the decision still last or not. In case the reasons cease, the court has to decide on following upbringing of the child again. A temporary foster care may be determined for maximally one year [10].

All rights and obligations of foster parents follow from the act No. 2012-89 Coll. Civil Code and from the act No. 1999-359 Coll. on the Social and Legal Protection of Children. Those rights and obligations are identical with all rights and obligations of long-term foster parents [8].

\subsection{Boarding out a child with another natural person}

Putting a child in the custody of some other natural person is provided in articles 953-957 of the act No. 2012-89 Coll. Civil Code. It is the first choice institute in case when for some reasons children cannot live with their parents. The court often puts a child in the custody of a relative or other close person who has an attachment with the child [7].

\subsection{Tutelage}

The tutelage is also determined judicially in case that none of child's parents exist anymore (e.g. on account of death). According to the law a curator fully bears the parental responsibility towards a child, a curator becomes child's legal representative except for maintenance obligation. (Article 928 of the act No. 2012-89 Coll. Civil Code) The tutelage is materially supported by the state [7].

\subsection{Adoption}

The adoption is established by the judicial decision on the basis of adoptive parent's motion. It is provided by articles 794-854 of the act No. 2012-89 Coll. Civil Code. The act No. 1999359 Coll. on the Social and Legal Protection of Children is used for processing applications and assessing adoption applicants. In accordance with the Civil Code the adoption means the acceptance of other person as their own (Article 794 of the act No. 2012-89). Bubleová delimits a cornerstone of the adoption institute as follows: "The meaning of the adoption is a child receiving a stable, safe family background that will protect the child and love the child as their own with all rights and obligations of biological parents" [7]. From this point of view the adoption may be understood as the highest level of the substitute family care [8].

\subsection{Substitute vs. biological parenthood}

Klimeš claims that despite the fact, that substitute and biological parenthood are very similar, the substitute parents need some knowledge, skills and abilities, which biological parents frequently do not need at all. One of them is the topic of relationship bonds. All substitute parents should know this topic or more precisely the whole process of establishing a relationship bond and safe binding of the child. Usually children with attachment disorders come to a substitute family care and those children need to create or recreate relationship bonds [11].

According to Bowlby, Vrtbovská, Brisch, and Vavrda the attachment is understood as a very close and complex bond that includes mutual feelings, understanding, sharing of one's emotions, acceptance, permanency and love between a child and a mother. It is the case of an invisible emotional bond between the main bonding figure (because there exist strong dispositions to bond oneself to a particular person) and alternatively amongst other side 
bonding figures [12-15]. Relationship bonds may be divided into reliable and unreliable $[13,16]$. Unreliable relationship bonds are further divided in so called self-contradictory type, anxious type (parents' behaviour to the child is significantly inconsistent), evasive type (children whose parents are emotionally distant) and disorganised - disoriented type (an extreme version of one of preceding types) [13].

Brisch pointed out that an unreliable relationship bond could be considered as an adaptation pattern within the normal. He discourses disorders of relationship bonds. First of all he mentions an arguable absence of a relationship bond. Experts differ in their opinions on the possibility of relationship bond absence genesis. Those who claim that it really exists found it by children who had been institutionalized promptly after their birth. Undifferentiated bond behaviour means that the relationship bond is so disrupted that the child behaves in the same way to strange people and to close people. It is typical of neglected children who were very soon separated from their mothers. It is connected with risk behaviour in the context of a primary safety experience absence. Exaggerated bonding behaviour may be observed in children whose mothers suffer from anxiety disorder with an extreme fear of loss and also for mothers for who their children are simultaneously their own emotional base. A damped bonding behaviour is characteristic of mistreated children and children who have lived in a fear of physical punishments. An aggressive bonding behaviour appears by children who have commonly experienced an aggression in a family [14]. A bonding behaviour with converse roles emerges when child's parent seems to be needed. The child is so called available and puts her or his own needs in the background and brings parents'needs in the foreground. There may be observed some similar aspects as in the process of children parenthood - the topic of role gaps by Pesso and Boyden-Pesso [14, 17]. A relationship bond disorder with dependent behaviour appears in an infant age in the context of an experience when a parent does not have apposite reactions on child's needs. In this case the bonding person is replaced by some substitute - a substitutive object. Psychosomatic symptoms result from an emotional and physical neglecting [14].

This is the reason why substitute parents need to be not only well-educated but also wellprepared for meeting a child who will show signs of attachment or straight relationship bond disorder. It is also important that the people in question must be able to provide a safe, kindhearted and healthy relationship and also an emotional tie. Last but not least substitute parents are expected to understand child's troubles and to accept the child no matter what she or he is like $[8,13]$. Vrtbovská depicts demands that are in this context placed on substitute parents: "To be a parent of a child who has an attachment disorder is probably one of the most difficult parental tasks in the world" [13].

On the basis of above mentioned it may be stated that the foster care institute is well protected by the law in the Czech Republic and the system of foster parents' preparations is worked out. Non-profit organisations ensure the preparations of foster parents apart from the state. Centre of substitute family care Amalthea is one of those non-profit organisations that provide service to foster and adoptive families and also to families in which is child's development endangered. The organisation is authorised to execute an social and legal protection of children according to the act No. 1999-359 Coll. on the Social and Legal Protection of Children. Its vocation is to jointly form conditions for a healthy development of children in substitute families through meetings, accompanying, consultancy and education [18].

\section{Purpose of the study}

The research goal of this study was to ascertain a retrospective experience of foster families that they have had in their preparations before taking a child in a foster care and also during 
the process of having the child in their care. Research question - what is the experience of foster families in the Czech Republic with a process of preparation for a substitute family care?

\section{Research sample and methods}

Research sample - 20 foster parents - 10 women, 10 men. For an ascertainment of detailed and authentic respondents' statements was used a qualitative approach, a method of data collection was a half structured interview and data analysis was inspired by an embedded theory [19-21].

First of all, two pilot interviews were done to eliminate questions that could seem difficult to understand. Those pilot interviews also served as the support in adding the final touches to some items. They referred mainly to the topic of relationship bonds and the topic acquired more importance in next stages of the research. We were audio-recording each interview to literally transcribe the speeches later.

Considering the sensitivity of the topic we paid attention to observe the moral rules of the research. Respondents were informed on the aim of the research and on their right to back out of the research any time. All pieces of personal information that could lead to identification of particular individuals were struck from the transcription.

We kept the rule of open coding and categorization according to above mentioned methodological sources.

\section{Results}

The results of the analysis indicate that respondents find their professionally led preparation insufficient and this opinion is stronger by those respondents who had been foster parents for longer time. During their preparations respondents lacked especially topics on relationship bonds.

Authors state chosen categories of their research results that correspond to stated findings.

\subsection{Category 1}

A negative evaluation of the foster parents preparations led by the state in the context of relationship bonds. Respondents agree that there was not mentioned the problematic and the importance of relationship bonds during preparation courses for future foster parents led by the state. Those respondents also reckon the form of the preparation and its content as insufficient.

The interpretation of ascertained facts. Foster parents in the Czech Republic undergo a professional preparation led by the state which does not include a topic of relationship bonds. It seems that a future concrete experience differs from the general idea of the development of the relationship bonds building process. A child's personal history enters in the process of building relationship bonds. The child has to deal with feelings of loneliness and disclaimer and at the same time the child is being expected to be willing to bound itself to its foster parent. At this point the foster parent's vision and effort to implement the process of creating relationship bonds are confronted by the child's unique previous experience.

\subsection{Category 2}

An unreplaceable place of non-profit organisations during foster parents preparations. Not only in connection with the process of building relationship bonds respondents emphasize 
the function and help of different non-profit organisations that occupy themselves with a substitute family care and accompanying foster parents. Those organisations also procure education, practical courses and stays, where foster parents have chance to meet each other and to share their experience.

The interpretation of ascertained facts. This context may be influenced by different approach of state organisations and non-profit organisations. In both sectors (non-profit and state) exist controls that ascertain how the substitute family care is proceeding. In accordance with our findings foster parents find the manner of passing the control from the side of non-profit organisations as more acceptable though. Authors think that the reason is that the system of the social control in non-profit organisations is closely connected with the social help system. In the Czech Republic we can mention e.g. non-profit organisations Amalthea, Dobrá rodina, Natama.

\subsection{Category 3}

A gender-balanced view of the system of the substitute family care in the Czech Republic. Our respondents expressed the same experience and opinions across the gender. Both groups of research participants agreed in differences of their preparation and in an approach between state organisations and non-profit organisations which deal with the foster parents' preparation. Both men and women also had the opinion that it is necessary to pay a special attention to the topic of relationship bonds during process of preparations. The agreement was also on the opinion that women participate in the process of creating relationship bonds more strongly than men. The necessary support from the side of men was also emphasized.

The interpretation of ascertained facts. On the basis of the study may be stated that the study confirms generally accepted fact that a primary person who takes care of a child is mother. This is the reason why more requirements are put forward to mothers in connection with a substitute family care. This demand is being confirmed with no regard to an age and a sex of a child accepted by a family. Children who come to a family expect mother and father roles from their foster parents. Children have an implicit idea of how parents should fulfil their needs and also in what quality and rate the parents should do it. Children insist on meeting their requirements according to their ideas of different mother's tasks and father's tasks.

\section{Conclusions}

We found out that the substitute family care is an often discussed topic in the Czech Republic. On the one hand a potential substitute parents are calling for shortening of the whole process, but on the other hand researches show that substitute parents - especially foster parents consider the process of preparations as insufficient. This contradiction requires a discussion and an additional research. The relationship bonds seem to be one of the essential topics.

\section{References}

[1] B. Kraus, V. Poláčková a kol Člověk, prostředí, výchova (Paido, Brno, 2001)

[2] B. Kraus, Základy sociální pedagogiky (Portál, Praha, 2008)

[3] B. Kraus a kol, Životní styl současné české rodiny (Gaudeamus, Hradec Králové, 2014)

[4] P. Ondrejkovič, Soc. ped. 1, 48-63 (2013), http://soced.cz/medzigeneracnevztahy-v-optike-sociologickej-teorie_soced/

[5] J. Kovařík, Náhradní rodinná péče v praxi (Praha, Portál, 2004) 
[6] J. Nožîřrová, Náhradní rodinná péče (Linde, Praha, 2012)

[7] V. Bubleová et al., Základní informace o osvojení (adopci) (Středisko náhradní rodinné péče, Praha, 2014)

[8] A. Zimová, Vztahová vazba v náhradních rodinách (UHK, PdF, KSocP, 2015)

[9] Pěstounská péče na přechodnou dobu (2017), http://www.mpsv.cz/files/ clanky/13160/pestoun_prech_doba.pdf

[10] Zákon o sociálně právní ochraně dětí (2017), http://www.mpsv.cz/files/ clanky/7263/Zakon_o_socialne-pravni_ochrane_deti.pdf

[11] J. Klimeš, Budování identity dítěte (Občanské sdružení Rozum a cit, Říčany, 2008)

[12] J. Bowlby, Vazba: teorie raných vztahů mezi matkou a dítětem (Portál, Praha, 2010)

[13] P. Vrtbovská, O ztraceném dítěti a cestě do bezpečí - attachment, poruchy attachmentu a léčení (Scan, Tišnov, 2010)

[14] K.H. Brisch, Bezpečná výchova: budování jisté vztahové vazby mezi rodiči a dětmi (Portál, Praha, 2012)

[15] V. Vavrda, Otázky soudobé psychoanalýzy: tradice a současnost (Nakladatelství Lidové noviny, Praha, 2005)

[16] M.D.S. Ainsworth, Am. Psych. 34, 932-937 (1978)

[17] A. Pesso, D. Boyden-Pesso, P. Vrtbovská, Úvod do Pesso Boyden System Psychomotor (SCAN, Tišnov, 2009)

[18] R. Černá a kol, Cesta k dítěti. Terapeutické metody pro práci s dětmi v náhradní rodinné péči (Centrum náhradní rodinné péče, Amalthea, 2013)

[19] M. Miovský, Kvalitativní př́stup a metody v psychologickém výzkumu (Grada, Praha, 2006)

[20] J. Hendl, Kvalitativní výzkum: základní teorie, metody a aplikace (Portál, Praha, 2012)

[21] T. Řiháček, I. Čermák, R. Hytych, Kvalitativní analýza textů: čtyřri př́stupy (Masarykova univerzita, Brno, 2013) 